\title{
ASPECTS OF COMMODIFICATION OF RUSSIAN IN FINLAND
}

\author{
Hannes Viimaranta, Ekaterina Protassova, \\ Arto Mustajoki \\ University of Helsinki \\ 33 Fabianinkatu, 00014 Helsinki, Finland, P.O. Box 3
}

\begin{abstract}
This article examines the commodification of Russian in Finland, where recent decades have seen a sharp rise in the size of the Russian-speaking population and the number of tourists from Russia. We particularly consider the use of Russian in the fields of traditional and medical tourism, education, and culture - all of them areas where Russian tourists show a strong preference for services in their native language. The need to provide a variety of services in Russian means that proficiency in Russian is a significant asset on the job market, both for immigrants and for the relatively small number of Finns who can speak the language. We also note that there is considerable demand among Russian-speaking parents in Finland for educational services to supplement their children's school education.
\end{abstract}

Keywords: commodification of language, Russian language, Finland, tourism, medical tourism, education, culture

\section{INTRODUCTION}

This paper offers an insight into the commodification of Russian in Finland as part of a general process of the transformation of language use in the world (Heller 2010; Pavlenko 2015; Suryanarayan, this volume). We see commodification of language as a process that turns language into a 'measurable skill' and a 'marketable commodity' (Heller 2003: 474). This is particularly salient within the tourism industry that relies to a large extent on visitors from foreign countries. Utilization of communicative resources in tourism has two facets: on the one hand, it allows for commodification of language, culture, and identity as goods, and on the other, encourages exploitation of linguistic resources and communication skills (Heller et al. 2015: 563). The primary goal of efforts to valorize particular languages and speakers lies in market expansion and in strategies of distinction that frequently portray the ability to accommodate speakers of a particular language as an added value.

In Finland, knowledge of the Russian language and culture has become increasingly important since 1990 for two reasons: an increase in the number of Russian-speaking tourists visiting the country, and an influx of Russian-speaking immigrants from countries of the former Soviet Union. However, there has been no simultaneous increase in the number of Finns learning Russian: the proportion of schoolchildren receiving instruction in the language remains consistently below 5\% nationwide. Nevertheless, Finland has developed an effective infrastructure for services in Russian. To a great extent this can be attributed to migration of native Russian-speakers to the country and the consequent availability of Russian-speakers on the Finnish labour market.

In what follows, we will focus on several areas where language as capital plays an important role: tourism, medical services, education, and culture. These examples il- 
lustrate elements of Russian language and culture that became commodifiable as resources, commercially utilized for and by Russian-speaking residents and non-residents of Finland. Our observations and conclusions are based on our analysis of official statistics, survey data, and interviews with stakeholders. In the case of the Finnish healthcare industry, we also analysed Russian-language websites designed to attract Russianspeaking patients. By adopting a multi-sited approach in the analysis of the status of Russian within the country's tourism industry, it is our aim to highlight the key sites where Russian is commodified and constitutes a distinctive marketing argument for Russianspeaking markets.

\section{TOURISM}

According to research carried out by TNS Gallup Oy (2010: 27), Russian tourists take an exceptionally strong interest in cultural events: $76 \%$ of all respondents who visited Finland experienced something connected with culture (more than in the case of German, British, Swedish, or French tourists). In addition to sightseeing and shopping tourism, Russians are interested in a variety of cultural activities, such as museums, concerts, and exhibitions.

According to a report prepared by the Finnish Convention Bureau (Culture Finland 2014), Finnish institutions involved in cultural tourism did not, until recently, cooperate sufficiently with each other and did not adequately market their services to visitors from abroad. The report identified the key strengths that could be exploited, including the interest of foreigners in the Finnish cultural heritage, way of life, cuisine, design, architecture, games, film, and music. The target groups for the new cultural tourism programme called 'Culture Finland' include people with strong cultural interests from Europe, China, and Japan, including middle-class Russians aged between 25 and 55. The brand of 'Culture Finland' was propagated as 'the four Cs': credible, contrasting, creative, and cool, with tourism stakeholders recognizing that the way to attract new visitors is to invite them through the 'VisitFinland' website, specialized travel agencies, and social media. Until now, the cultural component in the advertising was only $0.1 \%$ in Moscow and 3.0\% in St Petersburg, while mainstream publicity featured hotel holidays, tours that include excursions, or visits to spas. Typical trips to Helsinki include visits to historic places like Suomenlinna (Sveaborg), the ensemble of the Senate Square, and the Church of the Rock. Lapland allures in winter with nature-related activities, Sámi culture, and Christmas-themed shopping and sightseeing activities. Marketing activities were largely centred on Moscow and St Petersburg as Russia's largest urban agglomerations with the highest per-capita income.

Language is a central element in the marketing efforts of Finnish tourism providers. The report by 'Culture Finland' (2014: 37) claims that only 29\% of Russians speak English even at the beginner level. Services should therefore be available in Russian, both as a necessity and as a competitive advantage in comparison with other tourism markets in Northern and Western Europe. The report emphasizes that, for visitors from Russia, information about products or services in the mother tongue is crucial for making purchase decisions. The stakeholders we interviewed also believed that Russians have a special interest in the shared history of the two countries, in cuisine, and in music. This has led tourism providers to organize thematic tours revolving around personalities like the composer Jean Sibelius or the writer Tove Jansson, or focusing on special events 
like film festivals or the 100th anniversary of Finland's independence in 2017. Services in Russian are important for all of these activities and include provision of Russianspeaking tourist guides, Russian-language websites, and printed materials such as leaflets and brochures. Mikkonen et al. (2015) analysed museum visits in Finland and found that Russian tourists attach great importance to cultural translation in addition to translation between languages. According to Plykina (2011), who studied the shopping behaviour of Russian tourists in the metropolitan area in the years prior to the Russian economic crisis, the main factors influencing consumers' choices were the spectrum of services and the safety of transactions. Russian-speaking tourists welcomed the quality and the novelty value of the products, and appreciated personal service in Russian. At that time, they were satisfied with the price level but dissatisfied with insufficient information. The number of Russian tourists was at its highest in 2013, when 5.2 million visits were recorded, but even in 2015, during the financial crisis and amid declining tourism numbers from Russia throughout Europe, 1.4 million Russian tourists came to Finland (Yle.fi 2016). Aside from their cultural interests, as many as $80 \%$ of the 20,000 respondents stated that they came to buy food. Altogether, Russians spent an average of 142 euros per trip in 2014, and 155 euros in 2015, much of this stemming from daytrips and shopping tourism.

Religious travel and pilgrimages are also very popular in modern Russia, and the Orthodox churches and monasteries in Finland attract significant numbers of visitors from Russia. The main destination, offering overnight accommodation to pilgrims and other visitors, is the Uusi Valamo (New Valamo/Valaam) Orthodox Monastery in Heinävesi (www.valamo.fi), along with the nearby Lintula Convent. While both of these monasteries are now essentially Finnish-speaking, they feature informative websites in Russian and appear to have discovered the economic potential that lies in the provision of services to Russian-speaking pilgrims and tourists. In the case of the Lintula Convent, Russian is the only language available on its website apart from Finnish ${ }^{1}$. It appears to us that while the interests of Russian tourists are widening, they continue to rely on affordable touristic offers and services in their mother tongue. According to an interview we conducted with a multilingual person who worked at the Helsinki Tourist Information Centre in summer 2016, the places of interest that Russian tourists most commonly enquired about were two contrasting destinations, the Linnanmäki amusement park and the Chapel of Silence. The tourists were also interested in finding free parking space. When filling in questionnaires about their experiences, they often commented that they loved to be addressed in Russian.

\section{MEDICAL SERVICES AND MEDICAL TOURISM}

Another significant form of tourism among upper-middle class Russians is medical tourism, that is travel abroad for medical care. This tourism is motivated by distrust of the Russian healthcare system, leading many sufficiently well-to-do patients to seek treatment abroad (cf. Muth 2017). In recent years, though, the financial crisis in Russia has resulted in a drop in both medical and traditional tourism. While it is difficult to obtain reliable statistics about the number of Russians travelling abroad to receive medical care, analysis of Internet searches related to medical tourism on the major Russian search

\footnotetext{
${ }^{1}$ http://www.valamo.fi/ru/ and http://www.lintulanluostari.fi/?lang=ru.
} 
engine Yandex shows a substantial decrease in interest from January 2014 to January 2016 (Kononov 2016). Israel, Germany, and Switzerland have been major destinations for people from the European part of Russia, while South Korea has attracted patients from the Russian Far East. Finland, for its part, does not have a long tradition of receiving medical tourists from Russia or elsewhere, but in recent years a concerted effort has been made to attract more foreign patients to Finnish clinics. To a large extent this was motivated by Finland's own economic crisis, by rising costs within the country's public healthcare system and the desire to fill Finnish hospital beds with self-paying private patients from abroad. Equally, the economic crisis led to decreasing spending in the private medical sector, prompting healthcare providers to find additional sources of revenue beyond the domestic healthcare market. The aim of a government-supported programme called 'FinlandCare', initiated in 2011, is to promote more than 50 Finnish healthcare providers on international markets via a multilingual website that also includes Russian'; its network of partners includes a marketing agency in St Petersburg. There is also a private company, 'SuomiMed' that operates as a healthcare broker on Russian-speaking markets, organizing patient visits from Russia to Finland. An interview with Sergey Stelmakh, the coordinator of SuomiMed ${ }^{3}$, was published in the bilingual monthly Финляндский торговый nуть/Venäjän kauppatie in 2014; here the number of Russian patients who had visited Finnish clinics in the previous year was estimated at just over one thousand (Jakkonen 2014).

Russians seeking medical treatment abroad can consult a number of non-countryspecific websites, most of which belong to agencies acting as intermediaries between patients and clinics. We examined the prominence of Finnish clinics on a number of sites that can be easily found by searching for 'лечение за рубежом' or 'за границей' ('mеdical care abroad') on search engines such as Yandex and Google. On 'mednapravlenie.ru', which is an information portal rather than an agency, Finland is listed among 34 countries as a provider of quality medical care. The number of Finnish clinics listed currently stands at 25 , while corresponding figures for countries of broadly comparable size include 13 for Hungary, 15 for Lithuania, 22 for Estonia, 28 for Bulgaria, 32 for Latvia, 49 for the Czech Republic, and 66 for Switzerland (with Germany featuring most prominently with 95 entries). A more selective commercial information portal, 'www.topmedclinic.com', lists 7 Finnish clinics, which compares reasonably well with countries like Switzerland (9) and Germany (10); moreover, in a non-alphabetical presentation of a total of 30 countries, Finland ranks third. Among the agency websites, 'www.lezard.ru' represents 12 countries, including Finland, and lists 7 Finnish clinics or organizations. However, 'www.recomed.ru' lists only 3 Finnish clinics among an advertised total of 800 health care providers in 40 countries. On 'ru.bookimed.com', Finland is not among the 23 countries on offer. Similarly, 'www.royalmedgroup.com' works with clinics in 12 countries that do not include Finland, and the situation is similar on 'www.med-turizm.ru'. Overall, Finland is not a major destination for medical travel among Russians, but compared to other Western European countries it may well be in a relatively advantageous position within current economic conditions. In particular, the geographical proximity to St Petersburg makes Finland a convenient option for

\footnotetext{
2 http://www.finlandcare.fi/web/finlandcare-ru.

http://www.suomimed.fi.
} 
people from the northwest of Russia, while the availability of frequent flights and a direct train connection make it potentially attractive for patients from the Moscow region. Finland certainly appears to be the only Nordic country attracting substantial numbers of medical tourists from Russia: none of the websites we examined listed clinics in Denmark, Norway, or Sweden.

Some of the clinics listed on the above-mentioned Russian-language websites do not make it clear what level of service they are able to provide in Russian, but there are examples of Finnish healthcare providers whose websites contain extensive information in Russian, and in some cases an explicit promise that Russian-speaking personnel will be available.

Clinics that operate Russian-language websites and have at least some Russianspeakers among their staff in Finland include 'Orton', which specializes in orthopaedics and ophthalmology, as well as 'Docrates', specializing in oncology. On its website, Docrates states that patients from Russia will be assigned a Russian-speaking coordinating nurse for the duration of their stay and that documents relating to their medical history are accepted in Russian. Similarly, Clinic Helena in Savonlinna in Eastern Finland and in close proximity to the Russian border specializes in breast cancer treatments, gynaecology, and plastic surgery. The clinic has a Russian-language website ${ }^{6}$ and guarantees service in Russian for Russian-speaking patients.

Another Finnish health care provider that has made a special effort to reach out to patients in Russia is HYKSin $\mathrm{Ltd}^{7}$, a private clinic outsourced from the Helsinki University Hospital. It was founded in 2013 following a change in legislation that allowed public healthcare providers to establish private enterprises and cater to international patients. According to a recent press release, $70 \%$ of HYKSin patients come from abroad and the company's Key Account Manager Petri Jalovaara (a Finn whose educational background includes a degree in Russian translation and interpreting) has indicated in an interview for a St Petersburg medical website that half of the foreign patients are Russians (Medtown 2016). HYKSin's website is multilingual and available in Russian, Finnish, Swedish, and English. The clinic is evidently interested in consolidating its position on the Russian market and has started to offer free consultations with its key account manager in St Petersburg, organized on a monthly basis in a central location. The services of the Kuopio University Hospital are also conveniently available to patients from Russia, in this case through the mediation of FinnMedTravel ${ }^{8}$, a broker based in both Finland and Russia. FinnMedTravel also cooperates with the Kuopio-based 'InOva'9 clinic, offering fertility treatments and maternity services.

The MedFIN medical centre in Helsinki, whose head physician is an immigrant from Russia, profiles itself as a clinic specializing in non-surgical aesthetic medicine on its Finnish website ${ }^{10}$ (www.medfin.fi), but similar to 'InOva' operates a separate

${ }^{4} \mathrm{https} / / /$ www.orton.fi/ru/glavnaja.

${ }_{6}^{5} \mathrm{https}: / / \mathrm{www} \cdot d o c r a t e s . c o m / \mathrm{ru}$.

${ }^{6} \mathrm{http}: / /$ klinikahelena.ru.

${ }^{7} \mathrm{https} / / / \mathrm{www} \cdot \mathrm{hyksin} . c 0 \mathrm{~m} / \mathrm{ru} /$ glavnaya.

${ }^{8}$ http://finnmedtravel.ru.

$9 \mathrm{http}: / /$ www.inova.fi/venaja1.

${ }^{10} \mathrm{http}: / / \mathrm{www} . m e d f i n . f i$. 
Russian website (www.medfin.ru) where the clinic advertises a wide range of medical services available in Russian, including assistance with childbirth. Giving birth in Finland is an option that interests substantial numbers of Russian women, arguably because of the state-of-the-art care during and after childbirth. The staff at HYKSin were surprised by the popularity of maternity services among Russians (Medtown 2016), and an Internet search for роды в Финляндии ('giving birth in Finland') yields a large number of entries, mostly containing positive accounts of Russian mothers' personal experiences.

Apart from the clinics that have taken steps to attract patients from Russia in Russian, there are also some healthcare providers that make an effort to offer services in Russian principally for patients resident in Finland, although they do welcome patients from Russia and are listed on the 'mednapravlenie.ru' portal. Diacor (www.diacor.fi), a company operating a chain of medical centres in the Helsinki region and in Turku, is a prime example: a full version of the website is available in Russian, a list of over thirty Russian-speaking doctors is provided. A telephone service in Russian is available four days a week, and in addition to that there is an email address for customer service in Russian. It is also interesting to note that Russia's favourite Finnish actor Ville Haapasalo has appeared in Diacor's Russian-language advertising material as an example of a satisfied patient, albeit one who presumably speaks Finnish to the doctors.

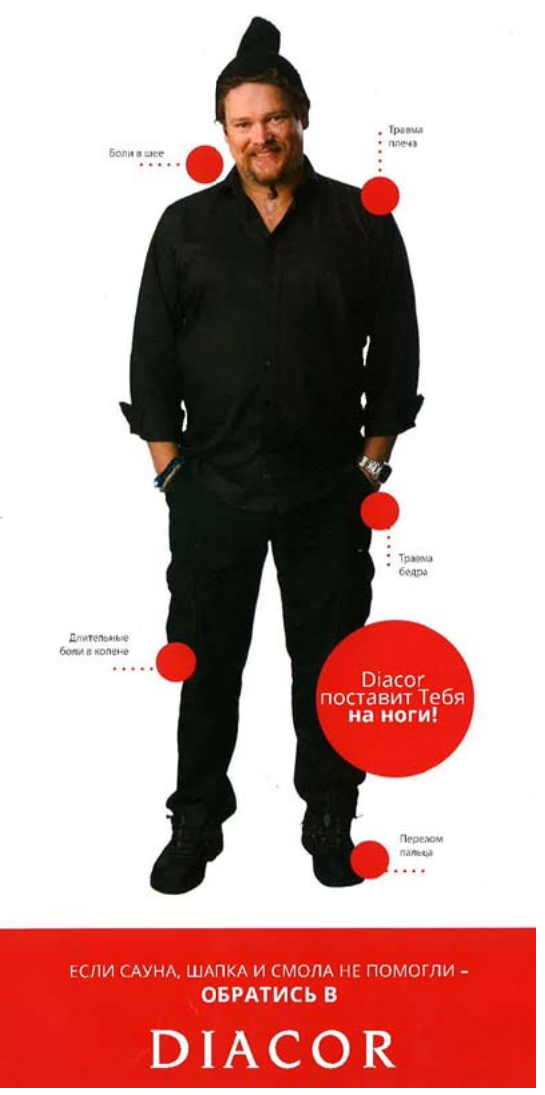

Figure 1. Ville Haapasalo recommending Diacor to Russian-speaking patients (with the small red dots showing injuries he has had at various times) ${ }^{11}$

${ }^{11}$ Retrieved from http://www.diacor.fi. 
One of Diacor's major competitors, Mehiläinen (www.mehilainen.fi), does not operate a Russian-language website or telephone service. Instead, patients with a basic command of Finnish, Swedish, or English can use the search facility on the website to find a Russian-speaking doctor. According to data retrieved on 20 September 2016, out of a total of 695 general practitioners working for Mehiläinen, 45 working in various Finnish cities indicated that they were able to communicate with patients in Russian. The total number of Russian-speaking doctors including both general practitioners and specialists working at Mehiläinen was 85 . We sought further information about these doctors in Suomen lääkärit (Parkkila-Harju 2013), a compendium of Finnish medical doctors, and found entries for 68 Russian-speaking doctors. The absence of entries for the rest could be explained by recent graduation, recent arrival in Finland, or change of surname. It turned out that just over half of the Russian-speaking doctors (35 out of 68) had been trained in Russia. These were mostly native speakers of Russian born in Russia or in countries of the former Soviet Union, but the figure also includes eight doctors born in Finland (and presumably native speakers of Finnish) who had taken a medical degree in Russia. Another large group of Russian-speaking doctors consisted of those trained in Estonia (19); most of these were presumably native speakers of Estonian, although a few had names suggesting a Russian background. Another four had been trained elsewhere in the former Soviet Union (three in Ukraine and one in Uzbekistan). There were only nine Russian-speaking doctors of Finnish origin who had been trained in Finland, presumably learning Russian as a foreign language. This is more or less consistent with the low overall popularity of Russian as a foreign language in Finland.

\section{EDUCATION}

Education is another site that to a certain extent relates to commodification of Russian in Finland by highlighting conditions that make commodification possible. While offering education in Russian to the local Russian-speaking population in itself does not entail commodification, teaching Russian creates the conditions that allow for commodification of Russian and may help maintain the favourable image of Finland as a tourist destination in the future.

The teaching of Russian in Finland is largely organized by non-governmental actors, many of whom operate on a for-profit basis, catering for children of Russian-speaking residents in the country. At the pre-school level (ages up to 7 under the Finnish system), Russian is one of the all-day languages in the cooperative kindergartens organized by the Society for Support of the Finnish-Russian School ${ }^{12}$ (Kalinka, Teremok, Matrjoshka) and in private kindergartens run by Idelia ${ }^{13}$ (Notka, Buratino, Ulybka, Pikku Enkeli, Ogonjok), Newkids ${ }^{14}$ (Puistikko, Dino, Alppiruusu), or Tik Tak ${ }^{15}$ (Pukinmäki, Malmin-

${ }^{12} \mathrm{http}: / /$ www.svk-kannatus.fi.

$13 \mathrm{http}: / / \mathrm{www}$.idelia.fi.

${ }^{14} \mathrm{http}: / /$ www.newkids.fi.

$15 \mathrm{http} / / /$ www.detsad-tiktak.com. 
kartano). There are bilingual Finnish-Russian day care centres in other regions of Finland as well, for instance, in Turku, Kotka, and Porvoo.

At school level, the options for bilingual education in Finnish and Russian are relatively limited. The main providers are the state-funded Finnish-Russian School (Suomalais-venäläinen koulu) and the municipal Myllypuro School (Myllypuron peruskoulu) in Helsinki, Puolala School in Turku (Puolalan koulu), and the Finnish-Russian network school of Eastern Finland (Itä-Suomen koulu) located in Imatra, Joensuu, and Lappeenranta. However, the vast majority of children from Russian-speaking families attend monolingual Finnish schools, with the option of two hours of Russian a week in classes designed for native/heritage speakers.

The Finnish education system is widely regarded as one of the best in the world, and a book explaining the rationale behind Finnish educational thinking by Sahlberg (2011) has recently been translated into Russian (Sahlberg 2015). Even so, many Russian-speaking parents in Finland are critical of the school system. As part of our EUfinanced PIM project Development of Parent Involvement Models for Bilingual Preand Primary School (2015-2017), we conducted a survey (obtaining 375 answers) in which many Russian-speaking parents indicated that they want their children to receive a better education, or simply much more education, than they can get at a Finnish school. Many of them (51\%) also believe that a good command of Russian can help their children to find employment. Children from these families frequent optional lessons, circles, clubs, and the school at the Russian embassy if they happen to live in the greater Helsinki area. The Muzykanty ('musicians') Children's Cultural Centre ${ }^{16}$ (Lastenkulttuurikeskus Musikantit) is a prime example of a non-profit bilingual organization, offering pre-school educational activities in both Russian and Finnish in the fields of music, dance, art, theatre, and languages. They organize various activities for parents during the time when their children are occupied, as well as festivities and events for the whole family. Русскоязычные Финляндии ('Russian-speakers in Finland') '17, an organization created in 2015, also offers a variety of educational activities as part of its general mission to support Russian-speakers in Finland in their efforts to integrate into Finnish society while maintaining their cultural identity. There are other societies that support language maintenance and identity formation among Russian-speaking and bilingual children, all of which occasionally invite visiting specialists to shed light on bilingual child-rearing. Educational camps in Russian are organized during school vacations, both for Russian-speaking children living in Finland and for children from Russia.

Finnish universities also attract students from Russia and the CIS. Many choose to remain in Finland after graduation, thus becoming long-term users and frequently also providers of services in Russian, constituting a highly skilled Russian-speaking workforce. This growing contingent of young Russian-speaking parents creates a demand for diversity when it comes to educational options in Russian, including bilingual pre-school education.

\footnotetext{
16 http://www.musikantit.fi.

$17 \mathrm{http}: / /$ svkeskus.fi.
} 


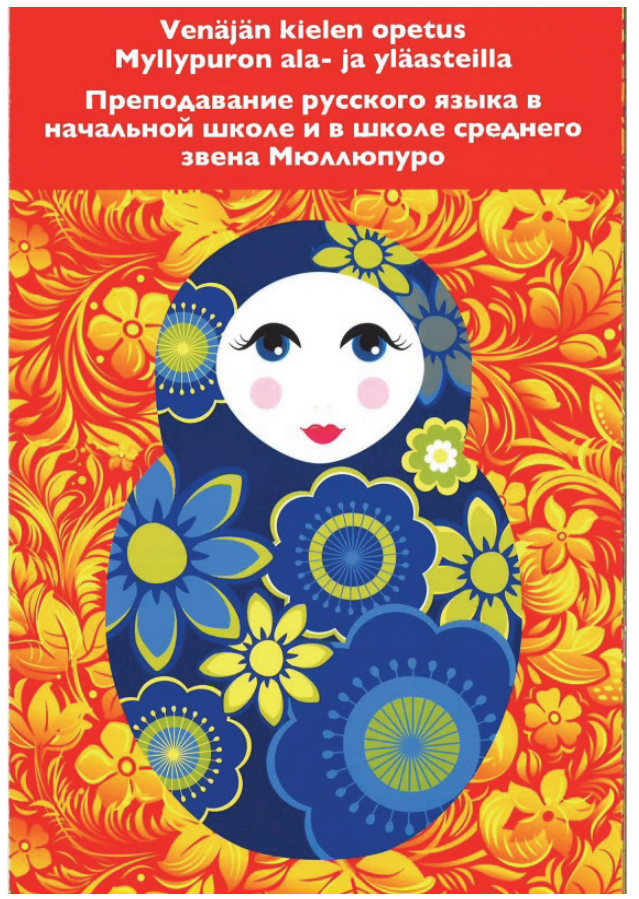

Figure 2. A brochure advertising bilingual education at Myllypuro School

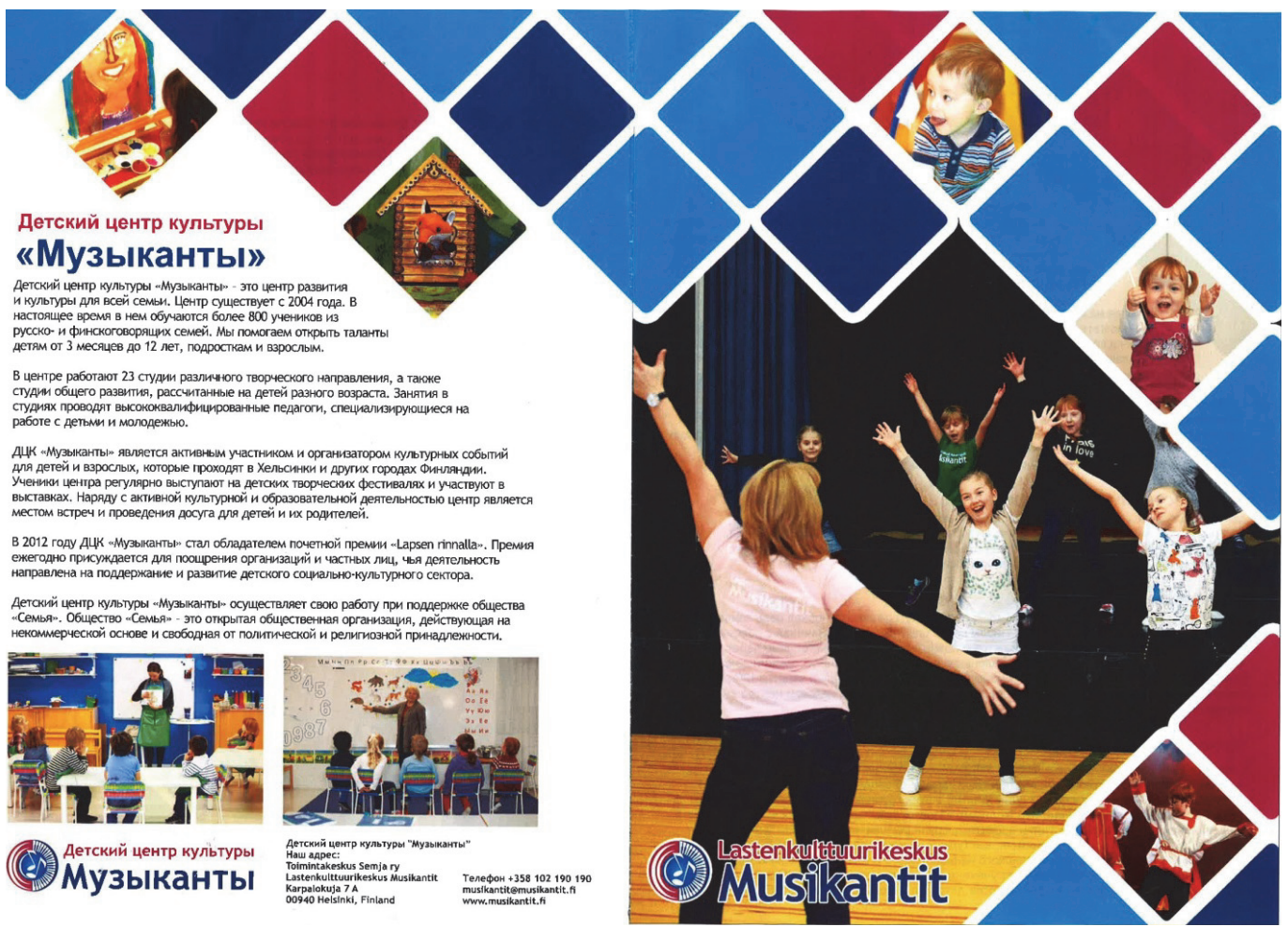

Figure 3. A brochure in Russian for the Muzykanty Children's Cultural Centre (reproduced by permission) 


\section{CULTURE AND MEDIA}

The Finnish authorities have taken a strong interest in the provision of cultural services for (and often by) the growing number of Russian-speakers living in Finland. Reports have been commissioned on the cultural needs of Russian-speakers (e.g. Lammi, Protassova, 2012), and many of the recommendations have led to concrete results. For example, the Russian language library ${ }^{18}$ at the Sello shopping mall in Espoo houses a collection of more than 15,000 books in Russian and arranges various projects for families with children (peer groups, reading and writing groups, meetings with Russian writers, concerts, etc.) and for the elderly. The 'Cultura Foundation' ${ }^{19}$ (Cultura-säätiö) started its activities in 2013 and aims to connect Russian-speakers in Finland and Finns interested in Russian language and culture; furthermore, it provides funding for a variety of mostly cultural projects.

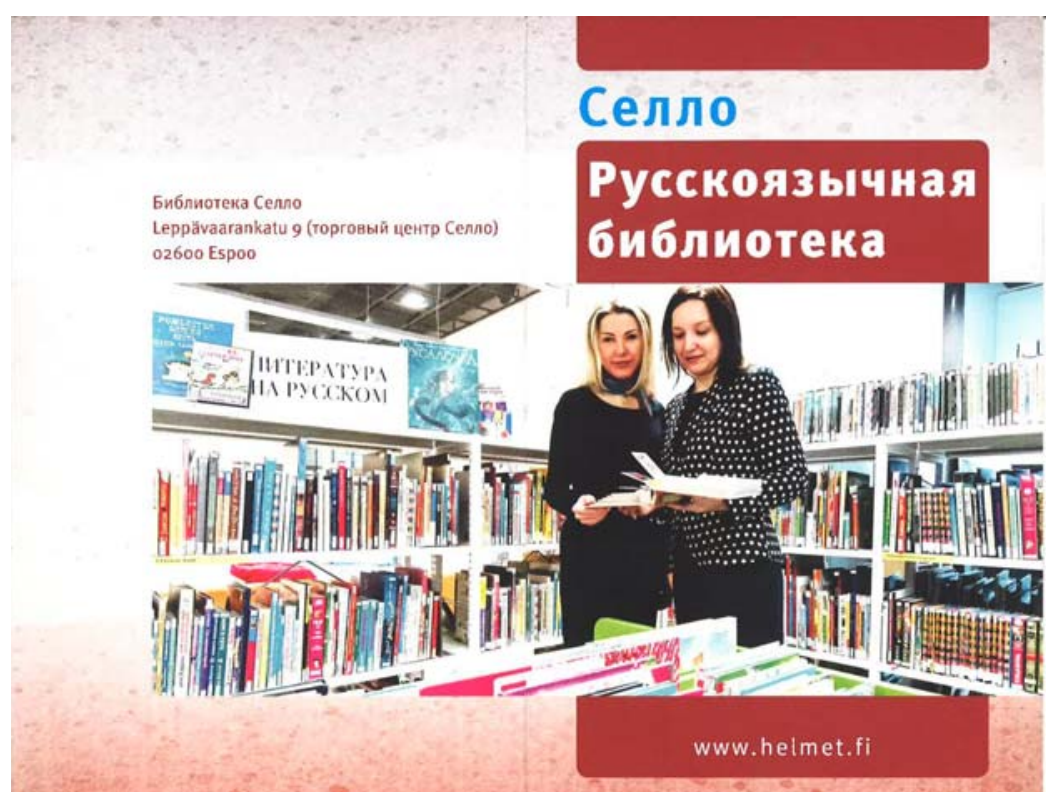

Figure 4. An advertisement for the Sello Russian library, Espoo

Russian professional theatre in Finland has a long history dating back to tsarist times (Byckling 2009). Amateur theatre in Russian was also popular between the two world wars (Baschmakoff and Leinonen 2001). Both types of performances are popular today and there is also demand for theatrical productions from Russia. For example, in the autumn of 2016 the Aleksanteri and Savoy theatres featured popular drama, ballet, and opera. Children's shows are always fully booked, especially during vacations. The new Russian-speaking TeatrZa, set up by a Russian actress and a Finnish actor trained in St Petersburg, opened in Helsinki in 2015. Many cultural centres invite guests from Russia.

Young Finns go to Russia to study arts and drama and return with mastery of Russian. Afterwards, they organize various events connected to Russia, such as the Russian

${ }^{18} \mathrm{http}: / /$ www.helmet.fi/fi-FI/Kirjastot_ja_palvelut/Venajankielinen_kirjasto.

$19 \mathrm{http} / / / \mathrm{www}$. culturas.fi. 
Nights festival. Rock concerts with groups from Russia and Finland are organized by the Tusovka association, mostly run by Finns who have learned Russian as a foreign language and become immersed in the culture. The most prominent individual success story is that of the Russian-trained Finnish actor Ville Haapasalo, who is a household name in Russia and has presented several series of documentaries on Finnish television, mostly connected to Russia and countries of the former Soviet Union. A less famous but equally noteworthy example is Kirsi Tykkyläinen, a former lecturer in Russian at the University of Helsinki, who has subsequently served as programme director of the Moscow Film Festival and artistic director of the St Petersburg Film Festival.

Russian-language media provision has also increased in Finland as a result of the growth of the Russian-speaking population. In particular, the Russian service of the Finnish Broadcasting Company YLE provides regular news updates on the Internet and daily bulletins on both radio and television, with a particular focus on topics of interest to Russians in Finland ${ }^{20}$. Since 2013, the Finnish nationwide commercial TV network Alfatv.fi has shown programmes in Russian with subtitles in Finnish under the Finnish title Raja ('The Border'). A film project called 'Basaari' documented, among others, Russian-speakers in Finland; one of the topics was parents' experiences with bilingual upbringing, directed by Victor Belousov.

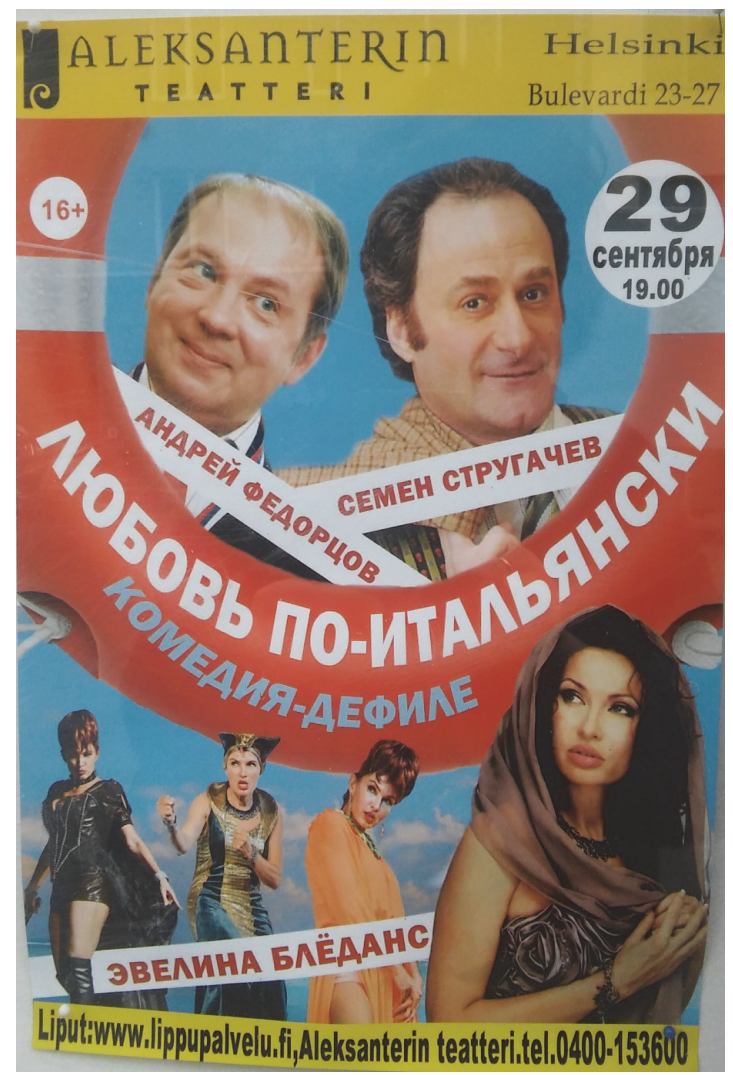

Figure 5. An advertisement for a Russian-language variety show at Aleksanteri Theatre, Helsinki

${ }^{20} \mathrm{http}: / /$ yle.fi/uutiset/osasto/novosti. 
Despite the small number of Finns learning Russian, there is considerable interest in Russia and its culture among the Finnish-speaking population. Finnish academics and practitioners with specialist knowledge of Russia have thus been able to capitalize on their expertise by writing books in Finnish for the general public on various aspects of Russian culture and society and Finnish-Russian relations. No fewer than twelve such publications appeared in 2013 alone (Mustajoki and Protassova 2015: 72). In 2016, another ongoing project was granted sponsorship by the Finnish KONE Foundation: the Finnish journalist Jussi Konttinen, who specializes in intercultural communication and has been an active columnist on Russian topics for the leading newspaper Helsingin Sanomat, took his family (wife and three children) to live for a year in a small Yakut village 40 kilometres from Yakutsk (Konttinen 2016). He will describe his experiences in a book. He jokingly alludes to a Finnish saying 'Siberia will teach', i.e. one sometimes has to learn things the hard way; in his case, Siberia is at any rate going to teach his children the Yakut and Russian languages.

\section{CONCLUSION}

For historical reasons and because of national security, economic contacts, scientific cooperation, and cultural exchange, knowledge of Russian has traditionally been important in Finland, nonwithstanding the relatively small percentage of the population learning the language. In the post-Soviet decades, though, Russian competence has increasingly become a marketable commodity as a result of two parallel developments: a substantial increase in the number of Russian tourists visiting Finland, and an influx of Russian-speaking immigrants settling in the country. Tourism, health, education, and culture are some of the major fields in which demand for services in Russian has grown significantly. Russian-speaking immigrants have taken on an important role not only as users but also as providers of these services. The Finnish authorities have been supportive of initiatives aimed at increasing the availability of services in Russian, partly with a view to attracting Russian visitors, but also as part of a general policy of multiculturalism, where mother tongue retention in immigrant families is seen as making a positive contribution to successful integration. Demographic prognoses suggest that the Russianspeaking population in Finland will continue to grow for the foreseeable future. This will likely also have consequences for the status and the use of Russian in Finland, or at least will have a positive effect on the attractiveness of Finland among Russian-speaking tourists. Within conventional tourism and medical travel, growing numbers of Russian-speakers in Finland may contribute to the popularity of the country among Russian-speaking visitors, assuring the availability of touristic services in Russian. Given the fact that Russia is the country's largest neighbour and one of the most important tourism markets, offering tourist services in Russian may only strengthen the Finnish service industry.

(C) Hannes Viimaranta, Ekaterina Protassova, Arto Mustajoki, 2017

\section{REFERENCES}

Baschmakoff, N., Leinonen, M. (2001) Russian Life in Finland 1917-1939: A Local and Oral History. Helsinki: Tomus.

Byckling, L. (2009) Keisarinajan kulisseissa: Helsingin Venäläisen teatterin historia 1868-1918. Helsinki: Suomalaisen kirjallisuuden seura. 
Culture Finland (2014) Kulttuurimatkailun kehittämisstrategia Kansainvälisille markkinoille 20142018. Helsinki: Matkailun edistämiskeskus.

Duchêne, A. and Heller, M. (eds.) (2012) Language in Late Capitalism: Pride and Profit. New York: Routledge.

Heller, M. (2003) Globalization, the new economy, and the commodification of language and identity. Journal of Sociolinguistics 7/4, 473-492.

Heller, M. (2010) The commodification of language. Annual Review of Anthropology, 39, 101-114.

Jakkonen, Aleksandr (2014). Na lechenie i reabilitaciiu v Finliandiiu. http://www.kauppatie.com/ 2014/09-2014/rus-13.shtml.

Kononov, R. (2016) Rossiiskii rynok medicinskogo turizma: zavyshennye cifry i upavshii interes. https://vc.ru/p/recomed.

Konttinen, J. (2016) Lapset, nyt Siperiaan! HS Kuukausiliite, 9, 68.

Lammi, A., Protassova, E. Suomen venäjänkieliset kulttuuripalveluiden käyttäjinä ja tuottajina. Helsinki: Venäjän ja Itä-Euroopan instituutti, 2012.

Medtown (2016) V Rossii vse stremiatsia popast' k "khoroshemu vrachu" — finnam eto trudno poniat. http://medtown.ru/interview-finnclinic.htm.

Mikkonen, J., Pesonen, J., Honkanen, A. (2015). Kulttuurimatkailun vaikuttavuusindikaattorit. Esiselvityshankkeen 2013-2015 loppuraportti. Opetus- ja kulttuuriministeriön julkaisuja 20.

Mustajoki, A., Protassova, E. (2015) The Finnish-Russian relationships: the interplay of economics, history, psychology and language. Russian Journal of Linguistics, 23 (4), 2015, 69-81.

Muth, S. (2017) Russian as a commodity: medical tourism and the healthcare industry in postSoviet Lithuania. International Journal of Bilingual Education and Bilingualism, 20, 4, 404-416.

Parkkila-Harju, M. (ed.) (2013) Suomen lääkärit 2012 = Finlands läkare 2012. Helsinki: Suomen lääkäriliitto.

Pavlenko, A. (2015) Russian-friendly: how Russian became a commodity in Europe and beyond, International Journal of Bilingual Education and Bilingualism, DOI: 10.1080/13670050.2015.1115001.

Plykina, T. (2011) Venäläisten ostosmatkailu pääkaupunkiseudulla. Helsinki: Haaga-Helia.

Sahlberg, P. (2011) Finnish Lessons: What Can the World Learn from Educational Change in Finland? New York: Teachers College Press.

Sahlberg, P. (2015) Finskie uroki. Istoriia uspekha reform shkolnogo obrazovaniia v Finliandii. Moscow: Klassika-XXI.

STT Info (2016). Hyksin Oy ja Orton Oy syventävät yhteistyötään. https://www.sttinfo.fi/tiedote/ hyksin-oy-ja-orton-oy-syventavat-yhteistyotaan?publisherId=7961000\&releaseId=45928938.

TNS Gallup Oy (2010) Kiinnostaako Suomi kulttuurimatkailukohteena? Kartoitus Iso-Britanniassa, Ranskassa, Ruotsissa, Saksassa ja Venäjällä tarkastelee kyseisten maiden kansalaisten näkemyksiä kulttuurimatkailusta, heidän kulttuurin kuluttamistaan lomamatkoilla ja kiinnostustaan matkustaa Suomeen kulttuurilomalle. MEK A: 167.

Yelenevskaya, M., Protassova, E. (2015) Global Russian: between decline and revitalization. Russian Journal of Communication, 7(2), 139-149.

Yle.fi (2016) Teper pokupaiut tolko produkty pitaniia. 30.5. http://yle.fi/uutiset/teper_pokupayut tolko_produkty_pitaniya_za_proshlyi_god_rossiiskie_turisty_potratili_v_yuzhnoi_karelii_ 150_000_000_yevro/8917854.

\section{Article history:}

Received: 21 March 2017

Revised: 07 May 2017

Accepted: 10 June 2017 


\title{
For citation:
}

Viimaranta H., Protassova E., Mustajoki, A. (2017) Aspects of Commodification of Russian in Finland. Russian Journal of Linguistics, 21 (3), 620—634. doi 10.22363/2312-9182-2017-213-620-634.

\section{Bio Notes:}

Hannes Viimaranta, BA (Oxford), MA (Helsinki), is a former university teacher of Russian language and literature. He now teaches modern foreign languages at school level and continues to engage in research activities. Research interests: sociolinguistics, bilingualism, multilingualism, commodification of Russian language, education, language and culture. Contact information: e-mail: hannes.viimaranta@gmail.com.

Ekaterina Protassova, Ph.D., Associate Professor, Department of Modern Languages, University of Helsinki. Research interests: multilingualism in Russia and abroad, Russian speaking diaspora in the world (especially in Finland, Germany, Estonia, Latvia, Kyrgyzstan and Kazakhstan), the use of the modern Russian language, intercultural communication, bilingual education and language revitalization. Contact information: e-mail: ekaterina.protassova@helsinki.fi.

Arto Mustajoki, Professor, Dean of the Faculty of Arts, University of Helsinki, Vice-President of the International Association of Teachers of Russian Language and Literature (MAPRYAL). Research interests: Russian language, functional grammar, contrastive cross-linguistic studies, linguistic methodology, cross-cultural communication, miscommunication and linguistic tolerance. Contact information: e-mail: arto.mustajoki@helsinki.fi.

DOI: $10.22363 / 2312-9182-2017-21-3-620-634$

\section{КОММОДИФИКАЦИЯ РУССКОГО ЯЗЫКА в ФИнЛЯНдиИ}

\author{
Ханнес Виимаранта, Арто Мустайоки, \\ Екатерина Протасова \\ Университет Хельсинки \\ 33 Fabianinkatu, 00014 Helsinki, Finland, P.O. Box 3
}

В статье рассматривается вопрос о коммодификации русского языка в Финляндии, где в последние десятилетия резко увеличилась численность русскоязычного населения, а также количество туристов из России. Особое внимание уделяется использованию русского языка в сферах традиционного и медицинского туризма, образования и культуры. Спецификой туристов из России является повышенный интерес к культурным ценностям, а также явная склонность отдавать предпочтение услугам на родном языке. Новой тенденцией является рост медицинского туризма и маркетинговая деятельность финских клиник на российском рынке. Среди русскоязычных родителей в Финляндии существует большой спрос на дополнительные к школьному образованию занятия. В русскоязычной среде отмечается также высокая культурная активность. Необходимость предоставления различных услуг на русском языке значительно улучшает перспективы трудоустройства русскоязычных иммигрантов, а также тех относительно немногочисленных финнов, которые говорят по-русски.

Ключевые слова: коммодификация языка, русский язык, Финляндия, туризм, медицинский туризм, образование, культура

\section{История статьи:}

Дата поступления в редакцию: 21 марта 2017

Дата принятия в печать: 10 июня 2017 


\section{Для цитирования:}

Viimaranta H., Protassova E., Mustajoki, A. (2017) Aspects of Commodification of Russian in Finland // Вестник Российского университета дружбы народов. Серия: Лингвистика. 2017. T. 21. № 3. C. 620—634. doi 10.22363/2312-9182-2017-21-3-620-634.

\section{Сведения об авторах:}

Ханнес Виимаранта, окончил Оксфордский и Хельсинкский университеты, преподавал в университете русский язык и литературу. Работает школьным учителем иностранных языков, продолжает заниматься научными исследованиями. Сфера научных интересов: социолингвистика, билингвизм, мультилингвизм, коммодификация русского языка, язык и культура, образование. Контактная информация: e-mail: hannes.viimaranta@gmail.com.

Екатерина Протасова, кандидат филологических наук, доцент кафедры современных языков, Университет Хельсинки. Сфера научных интересов: многоязычие в России и за рубежом, русскоязычная диаспора в мире (особенно в Финляндии, Германии, Эстонии, Латвии, Киргизии и Казахстане), использование современного русского языка, межкультурная коммуникация, двуязычное образование и ревитализация языка. Контактная информаиия: ekaterina.protassova@helsinki.fi.

Арто Мустайоки, профессор, декан факультета гуманитарных наук, Университет Хельсинки, вице-президент Международной Ассоциации преподавателей русского языка и литературы (МАПРЯЛ). Сфера научных интересов: русский язык, функциональная грамматика, межкультурные исследования, лингвистическая методология, методы лингвистического анализа, межкультурная коммуникация, языковое непонимание, языковая толерантность. 